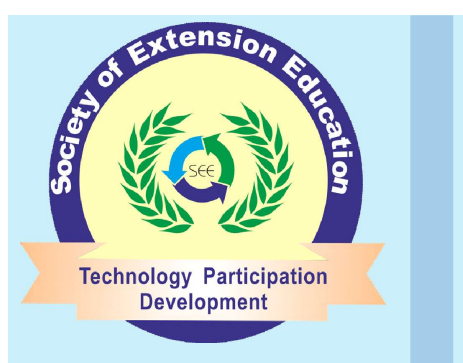

Research Article

\section{Indian Research Journal of Extension Education}

ISSN: 0972-2181 (Print), 0976-1071 (Online)

NAAS Rating : 5.22

Journal homepage: seea.org.in

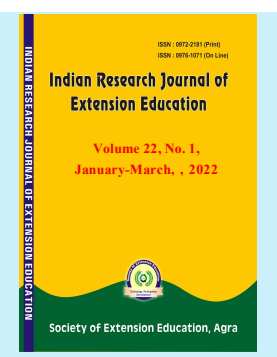

https://doi.org/10.54986/irjee/2022/jan_mar/55-59

\title{
Performance of High Yielding Promising Sugarcane Variety for Western Zone of Tamilnadu
}

\author{
S. Saravanakumar ${ }^{1}$ and T. Rajula Shanthy ${ }^{2}$ \\ 1. Scientist (Agronomy), ICAR-KVK, Myrada, Erode District, \\ 2. Principal Scientist \& Head, Extension, ICAR-Sugarcane Breeding Institute, Coimbatore \\ Corresponding author e-mail : agrisarwan@gmail.com
}

Paper Received on September 09, 2021, Accepted on Novembe 20, 2021 and Published Online on January 01, 2022

\begin{abstract}
Sugarcane is an important commercial crop cultivated in over 23,000 ha in Erode district of TamilNadu state. Attempts were made by researchers and extension workers to improve the productivity of sugarcane by adopting high yielding varieties and improved production technologies. The on-farm trials were conducted during Kharif 2017 and 2018 in five farmers' field to assess the performance of high yielding promising sugarcane varieties suitable for Western Zone of TamilNadu. The varieties selected for trial were Co 86032 and Co 0212. The study revealed that Co 0212 recorded more number of productive tillers per plant (10.4), intermodal length $(14.51 \mathrm{~cm})$, stem girth (11.22) and individual cane weight $(1.511 \mathrm{~kg})$ which was superiorly higher than the existing variety Co 86032. Similarly Co 0212 recorded the yield of 127.5 ton / ha during 2017 which was 17.24 per cent higher yield than the existing variety and 138.86 ton / ha recorded and 30.68 per cent yield advantage was noticed in the ratoon crop. The highest benefit cost ratio of 2.44 was recorded in Co 0212 in ratoon crop and 2.05 in first crop where as 1.73 and 1.86 BCR observed in Co 86032 in first and ratoon crop respectively. Considering the above facts, Co 0212 would be identified as a better alternate variety suitable for the Western Zone of TamilNadu.
\end{abstract}

Key words : Cane Yield; Co 0212; Economics; Sugarcane; Western Zone.

Sugarcane is an important commercial crop cultivated in over 2, 00, 000 ha in TamilNadu of which 10 per cent area being cultivated in Erode district. Sugarcane is the main source for sugar or sucrose in India. The states like Uttar Pradesh, Maharashtra, Karnataka, TamilNadu, Bihar, Andhra Pradesh and Gujarat are the major sugarcane growing states in the country. $\mathrm{Co}-86032$ is the predominant variety occupying nearly 93 per cent of the cultivable area in India and over 60 per cent in TamilNadu. Co 86032 has given a cane yield of $168.50 \mathrm{t} / \mathrm{ha}$ in frontline demonstrations conducted in farmers fields. (Rajula Shanthy, 2011).
The production potential of this variety is declining year by year due to continuous cultivation of same variety, susceptibility to pests \& diseases and loss in hybrid vigour. Though Tamil Nadu ranked first in terms of productivity in India, this is much lower than the production potential of $212 \mathrm{ton} / \mathrm{ha}$ of the crop (Waclawovsky et al. 2010). To meet the need of growing population expected to reach around 1.45 billion by 2025 and the increasing demand of sugar, production and productivity of the crop needs to be increased. The area under sugarcane cultivation is gradually decreasing in the state due to introduction of high value crops and poor return from 
the existing varieties. Since the land is shrinking, development of promising high yielding varieties and its popularization is required for enhancing sugarcane yield.

The area under sugarcane cultivation is drastically reducing from 35000 ha to 23,000 ha in Erode district in the past 10 years. The district is having three major sugar mills, which occupy 90 per cent of the total cultivated area for sugar production. Continuous drought also leads to crop replacement by other crops especially fodder Sorghum. The sugarcane farmers are in need of alternate variety which is suitable for drought and heavy ratoon yielder. The productivity of the crop could be increased by adopting improved production technologies, management practices and suitable varieties (Ranawat et al., 2011). Unawareness of new varieties and nonavailability of planting materials force farmers to recycle their own seed or planting materials which further complicate the situation. This has raised concerns to the breeders on the breeding for better sugarcane varieties and their subsequent introduction to the country. On farm trials have been found to be effective in the evaluation and selection of new varieties and technologies (Adjei-Nsiah et al., 2007) for their location specificity. Keeping this view in mind, ICARKrishi Vigyan Kendra, MYRADA conducted on farm trials on performance of high yielding promising sugarcane varieties for Western Zone of TamilNadu.

\section{METHODOLOGY}

On Farm Trial (OFT) is the concept evolved by Indian Council of Agricultural Research (ICAR) with the objective of identifying suitable varieties and technologies with farmers' participatory mode in real time farmers' fields to the specific agro climatic conditions. OFT was conducted in Poonthurai and periya semur village of Erode district, TamilNadu. Erode is situated in western zone of TamilNadu at $10.36^{\circ}$ to $11.58^{\circ}$ Latitude and $76.49^{\circ}$ to $77.58^{\circ}$ Longitude. The district receives maximum amount of rainfall during the North East Monsoon, however, the area is covered by canal irrigation water as well. The river Cauvery flows along the eastern border of the district.

OFT with farmers participatory mode was conducted during early Kharif season of 2017 and 2018 by involving five locations from Poonthurai and periya semur region of Erode district. The promising popular sugarcane variety Co 86032 and the new sugarcane variety Co 0212 were selected for the trial. The selected progressive farmers were trained in all scientific sugarcane cultivation aspects before starting of the trials. Planting was taken up during the second fortnight of May 2017 under assured irrigated conditions. Both the varieties were planted with a plot size of $40 \mathrm{~m} \times 25 \mathrm{~m}$. In order to ensure optimum plant population, the farmers were provided with well emerged single bud seedlings. The package of practices recommended by Tamil Nadu Agricultural University and ICAR - Sugarcane Breeding Institute (SBI) was adopted during the cropping period.

The trial plot fields were regularly monitored and periodically observed by the scientists of KVK, SBI and sugar mill officials. The data on parameters like number of productive tillers per plant, inter-node length, stem girth, individual cane weight and cane yield were recorded from the trial plots. The intermodal length of the cane was measured from one node to another node by using the measuring scale. The cane girth was measured by using measuring tape and individual cane weight was measured using electronic weighing balance.

At the time of harvest, yield data were collected from both the trial plots. The crop was rationed as being done by the sugarcane farmers and observations are taken up in the ratoon crop during 2018-19. For the convenience of statistical analysis, each varietal field was divided into two halves to get ten plots ( 5 farmers and every two plots), which served as replications. The cost of cultivation and profit details of both the systems were collected from the farmers for working out the economics and benefit cost ratio. The economics of different varieties was calculated by converting the total yield of the plot into money value. The cost of cultivation was estimated based on the prevailing market rate on expense. The gross return was calculated by adding the cost of cane according to prevailing market rates.

Gross return (Rs. /ha) $=$ Gross cost of cane (Rs./ha).

Net return obtained by subtracting the cost of cultivation from gross return.

Net return (Rs./ha) $=$ Gross return (Rs./ha) - Total cost of cultivation (Rs./ha).

B: C ratio was calculated as per the formula given below.

$$
\mathrm{BCR}=\frac{\text { Gross Return (Rs/ha) }}{\text { Total cost of cultivation (Rs./ha) }}
$$

$\mathrm{BCR}=$ Return per rupees invested

The data were subjected to statistical analysis (Gomez and Gomez, 2010). 


\section{RESULTS AND DISCUSSION}

The promising sugarcane varieties like Co 86032 and Co 0212 were selected and the special characteristic features of these varieties are presented in Table 1.

Table 1. Characteristic features of selected promising sugarcane varieties

\begin{tabular}{|c|c|}
\hline Variety & Special characteristic features \\
\hline Co86032 & $\begin{array}{l}\text { Wonder variety of the decade and } \\
\text { recommended for tropical zone. } \\
\text { This is a high yielding, high sucrose mid-late } \\
\text { maturing variety. } \\
\text { Cultivated in wide range of soils except water } \\
\text { logging. } \\
\text { - Av. cane yield obtained is } 120 \mathrm{t} / \mathrm{ha} \text {. } \\
\text { Resistant to smut, moderately resistant to wilt } \\
\text { and field tolerant to red rot. } \\
\text { - Gives } \mathrm{A}_{1} \text { quality jaggery with good quality. } \\
\text { In Tamil Nadu, it occupies over } 60 \% \text { of the area. }\end{array}$ \\
\hline Co 0212 & $\begin{array}{l}\text { - Erect and medium thick canes } \\
\text {. } \text { Gives good quality } \mathrm{A}_{1} \text { jaggery } \\
\text {. } \text { Good tillering ability } \\
\text {. } \\
\text { tolerant to drought and salinity } \\
\text {. Increased cane and sugar yield over Co } 86032 \\
\text {. } \\
\text { Average yield: } 156 \mathrm{t} / \mathrm{ha}\end{array}$ \\
\hline
\end{tabular}

The present study revealed that, the yield attributing parameters like productive tillers per plant, inter-node length, stem girth and individual cane weight was recorded to be higher in Co 0212 than Co 86032. The data relating to the yield attributing parameters are presented in Table 2. The average productive tiller of 10.4 numbers was recorded in Co 0212 which was superior to Co 86032. Similarly, inter-node length, stem girth and individual cane weight were recorded as 14.54 $\mathrm{cm}, 11.22 \mathrm{~cm}, 1.126 \mathrm{~cm}$ and $1.511 \mathrm{~kg}$ respectively whereas in Co86032 it was recorded as $11.0 \mathrm{~cm}, 9.8$ $\mathrm{cm}$ and $1.126 \mathrm{~kg}$ respectively. The significant variations in the yield attributing characters among the varieties may be due to their genetic variability and the influence of environmental factors. The findings of the present study are in line with Shukla et al., 2017 and Hiremath and Nagaraju (2009).

Table 3 further indicates that Co 0212 recorded 127.50 ton cane yield/ha during the first year (2017-18) which is significantly higher than Co 86032 (108.75 ton/ ha) and this amounted to 17.24 per cent yield advantage recorded in Co 0212 compared to Co 86032. Similarly, during 2018 -19, Co 0212 recorded a cane yield of 138.86 ton/ha which is significantly higher than Co 86032 (106.26 ton/ ha) and 30.68 per cent yield advantage

Table 2. Yield attributing parameters of promising sugarcane varieties (Data are cumulative average value for two years)

\begin{tabular}{|c|c|c|c|c|c|c|c|c|}
\hline \multirow[b]{2}{*}{ Locations } & \multicolumn{4}{|c|}{ Co 86032} & \multicolumn{4}{|c|}{ Co 0212} \\
\hline & $\begin{array}{c}\text { No. of } \\
\text { productive } \\
\text { tillers / plant }\end{array}$ & $\begin{array}{l}\text { Inter node } \\
\text { length } \\
(\mathrm{cm})\end{array}$ & $\begin{array}{l}\text { Stem } \\
\text { girth } \\
(\mathrm{cm})\end{array}$ & $\begin{array}{c}\text { Individual } \\
\text { cane weight } \\
(\mathrm{kg})\end{array}$ & $\begin{array}{c}\text { No. of } \\
\text { productive } \\
\text { tillers / plant }\end{array}$ & $\begin{array}{l}\text { Inter node } \\
\text { length } \\
(\mathrm{cm})\end{array}$ & $\begin{array}{l}\text { Stem } \\
\text { girth } \\
(\mathrm{cm})\end{array}$ & $\begin{array}{l}\text { Individual } \\
\text { cane } \\
\text { weight }(\mathrm{kg})\end{array}$ \\
\hline Location 1 & 6 & 10.8 & 9.9 & 1.326 & 12 & 14.6 & 11.6 & 1.584 \\
\hline Location 2 & 7 & 11.3 & 9.7 & 1.184 & 10 & 14.2 & 11.2 & 1.482 \\
\hline Location 3 & 6 & 11.2 & 10 & 1.072 & 10 & 15.3 & 10.9 & 1.505 \\
\hline Location 4 & 6 & 10.9 & 9.9 & 1.034 & 11 & 14.5 & 11.3 & 1.464 \\
\hline Location 5 & 5 & 10.8 & 9.6 & 1.015 & 9 & 14.1 & 11.1 & 1.518 \\
\hline Average & 6 & 11.0 & 9.82 & 1.126 & 10.4 & 14.54 & 11.22 & 1.511 \\
\hline
\end{tabular}

Table 3. Yield of promising sugarcane varieties during 2017-18 \& 2018-19

\begin{tabular}{lcccccc}
\hline \multirow{2}{*}{ Locations } & \multicolumn{2}{c}{ Yield of sugarcane varieties $(2017-18)(\mathrm{t} / \mathrm{ha})$} & \multicolumn{3}{c}{ Yield of sugarcane varieties (2018-19) $(\mathrm{t} / \mathrm{ha})$} \\
& Co-86032 & Co-0212 & \% yield increase & Co-86032 & Co-0212 & \% yield increase \\
\hline Location 1 & 110.4 & 129.2 & 17.03 & 108.7 & 140.5 & 29.25 \\
Location 2 & 107.3 & 134.1 & 24.98 & 104.6 & 144.8 & 38.43 \\
Location 3 & 109.5 & 124.5 & 13.70 & 105.8 & 132.9 & 25.61 \\
Location 4 & 108.9 & 122.8 & 12.76 & 107.3 & 136.7 & 27.40 \\
Location 5 & 107.65 & 126.9 & 17.88 & 104.9 & 139.4 & 32.89 \\
Average & 108.75 & 127.5 & 17.24 & 106.26 & 138.86 & 30.68 \\
\hline
\end{tabular}


Table 4. Economic parameters of the promising sugarcane varieties

\begin{tabular}{lllll}
\hline Economic parameters & \multicolumn{2}{c}{$2017-18$} & \multicolumn{2}{c}{$2018-19$} \\
& Co- 86032 & Co- 0212 & Co-86032 & Co- 0212 \\
\hline Yield (ton/ha) & 108.75 & 127.50 & 106.26 & 138.86 \\
Cane Rate (Rs / ton) & $2,350.00$ & $2,350.00$ & $2,350.00$ & $2,350.00$ \\
Gross cost (Rs./ha) & $1,47,500.00$ & $1,46,000.00$ & $1,34,500.00$ & $1,33,500.00$ \\
Gross Return (Rs./ha) & $2,55,562.50$ & $2,99,625.00$ & $2,49,711.00$ & $3,26,321.00$ \\
Net Return (Rs./ha) & $1,08,062.50$ & $1,53,625.00$ & $1,15,211.00$ & $1,92,821.00$ \\
BCR & 1.73 & 2.05 & 1.86 & 2.44 \\
\hline
\end{tabular}

was recorded in Co 0212 than Co 86032 in the ratoon crop. The results are in line with Singh et al. (2019) and Saravanakumar (2020).

The economic feasibility of improved practices over farmers' practices was calculated depending upon the prevailing prices of inputs and output cost are presented in Table 4. It was evident that, the cost of cultivation was recorded as Rs. 1,46,000 / ha in Co 0212 whereas it was recorded as Rs.1,47,500.00 / ha in Co 86032 during the first year. The variation in cost of cultivation was observed due to the incidence of inter-node borer and its management in Co 86032. Similarly, a gross cost of Rs.133,500 / ha was recorded in the ratoon crop. The gross return was worked out based on the prevailing price of cane provided by factories to the farmers. During the period, an amount of Rs.2,350 was provided per ton of harvested cane. Based on this, a net return of Rs. 153625 /ha was recorded in first crop and Rs. 192821.00 was recorded in ratoon crop. This was comparatively higher than the variety Co 86032. In Co 0212, the BCR was recorded as 2.05 in first crop and 2.44 in the ratoon crop, whereas 1.73 and 1.86 was recorded as BCR in Co 86032. These findings are in line with the reports of Raghav et al. (2021), Appunu et al. 2016 and Bakshi Ram et al. 2020. These results clearly indicated that the adoption of promising sugarcane variety Co 0212 with improved production technologies enhanced the productivity.

\section{CONCLUSION}

From the study, it was evident that new variety Co 0212 was found suitable in the western zone of TamilNadu. Adoption of new variety Co 0212 along with improved cultivation practices recorded higher yield than the farmers practicing variety Co 86032 . The higher yield attributing parameters and yield was recorded in the Co 0212 with 17.24 per cent yield increase in the first crop and 30.68 per cent yield increase in ratoon crop with the highest benefit cost ratio of 2.44 . Hence, the adoption of Co 0212 variety along with improved production technologies have a broad scope for increasing the production per unit area and it was accepted by the farmers for replacing of existing variety.

\section{CONFLICTS OF INTEREST}

The authors declare that they have no conflicts of interest.

\section{REFERENCES}

Adjei-Nsiah, S.; Kuyper, T.W.; Leeuwis, C.; Abekoe, M.K. and Giller, KE. (2007). Evaluating sustainable and profitable cropping sequences with cassava and four legume crops: Effects on soil fertility and maize yields in the forest / savannah transitional agro-ecological zone of Ghana. Field Crop Res., 103(2) : 87-97.

Appunu, C.A.; Annadurai, S.; Alarmelu, G.; Hemaprabha, M.N.; Premachandran, RajulaShanthy, T. and Bakshiram (2016). Sugarcane variety Co 0212 and its details. Extension publication No. 244. ICAR - Sugarcane Breeding Institute, Coimbatore

Bakshi Ram; Alarmelu. S. and RajulaShanthy, T. (2020). Promising sugarcane varieties. Extension publication No. 219. ICAR Sugarcane Breeding Institute, Coimbatore

Gomez, K.A. and Gomez, A.A. (2010). Statistical Procedures for Agricultural Research. $2^{\text {nd }}$ Edition. John Wiley and Sons, New York. Pp. 680.

Hiremath, S.M. and Nagarjau, M.V. (2009). Evaluation of frontline demonstration trials on onion in Haveri district of Karnataka, Karnataka J. of Agril. Sci., 22 (5) : 1092-1093 
Raghav, D.K.; Indrajeet; Kherwar, Dharmjeet; Kumar, Anjani; Singh, A.K. and Chauhan, Jitendra K. (2021). Role of frontline demonstration on chick pea for enhancing the production in district Ramgarh of Jharkhand. Indian Res.J. Ext. Edu., 21 (1) : $30-34$.

RajulaShanthy, T. (2011). Strategies for effective dissemination of appropriate technologies to sugarcane growers in India. Sugar techn., 13 (4): 354-359.

Ranawat, Y, Ram, H, Sisodiya and NK Punjabi. (2011). Adoption of improved maize cultivation practices by trained and untrained farmers of KVK, Udaipur. Rajasthan J.of Ext. Edu., 19 : 144 - 147.

Saravanakumar, S. (2020). Impact of improved sugarcane production technologies on pest incidence, Indian J. of Ext. Edu., $56(2): 93-95$.

Shukla, S.K.; Sharma, Lalan; Awasthi, S.K.; Pathak, A.D. (2017). Sugarcane in India: Package of practices for different agroclimatic zones. 1-64.

Singh, K.K., Singh, R.P.N. and Deepak Mishra (2019). Evaluation of front-line demonstration of oilseeds in Raebareli District. Indian J. of Ext. Edu., 55 (3): 49 - 52

Waclawovsky, A.J.; Sato, P.M.; Lembke, C.G.; Moore, P.H.; Souza, G.M. (2010). Sugarcane for bio-energy production: As assessment of yield regulation of sucrose content. Plant Biotech. Journal, $8: 263$-276. 